\title{
Environmental Literacy Mapping Based on Adiwiyata and Non Adiwiyata at Junior High School in Ponorogo
}

\section{Siti Nurwaqidah, Suciati, and Murni Ramli}

Indonesia

\section{Abstract}

This research is used to find out the effectiveness of adiwiyata program between national, provincial, district and non-adiwiyata schools on environmental literacy based on age and gender. The research was conducted at junior high school Ponorogo in march-october 2017. Type of research is ex post facto. Sampling technique used is Proportionate stratified random sampling technique. The assessment used the Middle School Environmental Literacy Survey (MSELS) standard supported by observational

Corresponding Author:

Murni Ramli

mramlim@fkip.uns.ac.id

Received: 18 January 2019

Accepted: 24 March 2019

Published: 31 March 2019

Publishing services provided by

Knowledge E

(c) Siti Nurwaqidah et al. This

article is distributed under the

terms of the Creative Commons

Attribution License, which

permits unrestricted use and

redistribution provided that the

original author and source are

credited.

Selection and Peer-review under the responsibility of the ICEST 2018 Conference Committee. data. The results of validity and reliability test on MSELI are valid and reliable. The results show that the adiwiyata program in ponorogo as a whole is related to the increase of environmental literacy with the sig value. 0.000. The higher the adiwiyata level, the higher the literacy value of the environment. Ability of environmental literacy among junior high school students between the ages of 13,14, and 15 years or more is not different, with sig value. 0.308 . The literacy ability of junior high school students environment between male and female sex is different, with the sig value. 0.004 . For general environmental literacy assessment in ponorogo is still low that more than $51 \%$ of respondents did not reach the score at level 3 which is the standard level of environmental literacy. The conclusions of the study were the types of levels of adiwiyata and gender affecting environmental literacy.

Keywords: Environmental Literacy, Environmental Education, Adiwiyata

\section{Introduction}

Human beings have an essential role towards the earth system. They face several issues globally, for instance, social, economy, and environment that are resulted from their activities toward the environment (NAAEE, 2011). The increase of population, the advancement of technology, and the improvement of the living standard are the causal factors of the increase of natural resources demand significantly so they affect the degradation of environmental quality (Kayihan\&Tonuk, 2013).A hug of the human need 
for natural resources affects the balance of nature (Pitman \& Daniels, 2016). Total population on the earth in 2017 is around 7.3 billion and is predicted to be increased around 9.8 billion in 20150 (Population Reference Bureau, 2017). The increasing of humans' dominant activities without awareness of environment management possibly affect environmental issues (Karatekin\&Aksoy, 2012). The increase in environmental issues is caused not only by inadequate management but also by ignorance, greed, inappropriate technology selection, lack of ethics and morals to the environment (PSIL, 2015).

One of the appropriate endeavors to tackle various environmental issues is to provide a more comprehensive understanding about environmental awareness. Environmental literacy is an awareness related to environmental health and the actions necessary to maintain, restore or improve environmental quality for sustainable environmental sustainability (Hollweg, 2011). Environmental literacy has several components, namely ecological knowledge, attitudes, environmentally responsible behavior, and environmental awareness (Karatekin, 2013).

Based on survey results on environmental community behavior from the Ministry of Environment in 2012 obtained the results of the national index value of changes in environmental care (IPPL) of 12 provinces in the survey only changed about 0.57 percent. Education is an important step in the process of changing people's behavior towards the environment (Conde\& Sanchez, 2010). The development of environmental literacy on students is a key objective in environmental education (Chu et al., 2007; Culen, 2005; Disinger, 2005; Hsu, 2004; McBeth\& Volk, 2010; NAAEE, 2004; Orr, 1990; Working Group Report on Environmental Education Living, 2007; Stapp et al., 2005; UNESCOUNEP, 1983). Environmental education needs to be done to prepare citizens to participate in efforts to create a sustainable environment and to increase awareness, responsibility, appreciation, and understanding of the importance of the environment and the impact of human activities on the natural environment (Chu et al., 2007).

The adiwiyata program began in 2006 and since 2007 there had been a significant increase in the implementation of the adiwiyata program. According to research Landriany (2014) states that adiwiyatahad not succeed to be implemented at high schools in Malang. This is in line with the research conducted by Rahmawati and Suwanda, 2015 indicating that Adiwiyata cannot be effectively implemented due to the change of students every new academic year, the socioeconomic condition of the students, and the educator's care. According to Krnel\&Naglic (2009) there is no significant difference between eco-school and nonschool in Slovenia. The researcher sees the importance of in-depth analysis as to whether the Adiwiyata program has been able or not to shape the 
environmental literacy among students both inside and outside schools as measured by the MSELI (Middle School Environmental Literacy Instrument) questionnaire developed by Mc.Beth.

\subsection{Literature review}

\subsubsection{Education of environment}

Education of environment under the UNESCO Convention (1997) is a process to create a world community who's an environmental concern and its related issues and who's the knowledge, motivation, commitment and skills to work both individually and collectively in finding alternatives or provide solutions to current environmental problems and to avoid the emergence of new environmental problems. The Education of environmentby Meilani (2011) stated that it basically aims to transform individual behavior into a positive behavior toward the environment (environmentally friendly behavior).

\subsubsection{Adiwiyata}

Adiwiyata is a good and ideal school as a place to gain knowledge, various norms and ethics that can be the basis of the human being towards the creation of welfare and the idea of sustainable development (LH Regulation No. 02 of the Year 2009). The objective of the Adiwiyata program is to create good conditions for the school to be a place for learning and awareness of the school's membersso that, the school's members can take responsibility towards the efforts to save the environment and sustainable development in the future (Ministry of Environment, 2012). There are several components and standards of a school categorized as adiwiyata, namely; 1) a policy of environment; 2) the implementation of an environment-based curriculum; 3) Participatory based environmental activities; and 4) management of thesupport facilitiesthat areenvironmentally friendly (Permendiknas 24, 2007). Adiwiyata based on the form and type of awards are divided into several levels namely; city-level Adiwiyata, province-level adiwiyata, national adiwiyata, and independent adiwiyata. A school which is labeled as regencylevel Adiwiyata is awarded by the Regent / Mayor and get award in form of a charter and a trophy. 


\subsubsection{Environmental literacy}

The environmental literacy is defined as the capacity to perceive, interpret the health of the systems in the environment and take appropriate steps to maintain, restore, or improve conditions intheenvironmentsystems (Ingbokwe, 2012). Another definition of environmental literacy is the knowledge of environmental concepts, issues, attitudes, motivations, cognitive abilities, skills, beliefs, and appropriate behaviors in order to make effective decisions in various environmental contexts (Hollweg et al., 2011). According to Elder (2003), the environment is one's ability to act appropriately in everyday life, to understand how individuals and societies relate to natural systems, and how to maintain a sustainable balance. The purpose of environmental literacy is to develop inquiry, investigation, and analytical skills; gain knowledge of the environment and human systemsprocesses; develop skills for understanding and dealing with environmental issues; train personally and as a citizen whose responsibility for the environment decisions (NAAEE, 1999; Archie, 2003). Environmental Literacy can be measured using MSELS instrument. The Indicators of the MSELS instrument fit to the Simmons framework as criteria in analyzing environmental literacy (Simmons in Chu et.al., 2007; Endorgan et.al., 2009). The components of Environmental Literacy that were adapted from Simmons are as follows: 1) Attitudes, 2) Ecological Knowledge, 3) Socio-political knowledge, 4) Environmental knowledge, 5) Cognitive skills, 6) Behavioral responsibility to the environment, 7) Additional determinants of behavioral responsibilities.

\subsection{Research methodology}

This research employed ex-post facto method. Data were collected using a standardized questionnaire survey. The instrument used was MSELS adapted from McBeth that had been tested for validity and reliability. The supporting data were obtained through observation and interview. The approach used was cross-sectional with instantaneous search and no respondent treatment. Sampling technique used is Proportionate stratified random sampling technique (proportional random sampling). According to Asra (2016), the stages in the sample survey activity were grouped into eight: 1) planning the content, preparing the cost, reviewing the literature, and making the hypothesis, 2) designing the sampling, sampling, 3) compiling the questionnaire, (pretest), make a survey manual; 4) selecting officers and exercises, 5) collecting data, 6) coding, 7) processing data and, 8) analyzing reports and answers to initial survey questions. Obtaineddata were analyzed by One Ways ANOVA, T-test, and descriptive. The subjects of the study were 
the students of grade VIII and IX of junior high schools in Ponorogo. The research was held in the odd semester of the academic year of 2016/2017.

\section{Result and Discussion}

Data collection in the survey research was conducted in 21 sub-districts in the total of 91 Junior High School. The total of Junior High School students in Ponorogo were 21.512, while there were 379 samples used from 21 sub-districts. The result of statistical test of environmental literacy consisting of four aspects, the average of ERB aspect has the highest average score to 74,18 then EA equal to 68,20 . The EK and ES aspects have the lowest average of 40.79 . While the sequence of maximum scores were ES, ERB, EK, and EA aspects. The minimum score aspect successively as ES, EK, ERB, and EA. The overall literacy score, EA, ERB, and ES were positive then the percentage of students who mostly have lower average. While the positive EK score indicated that most of the students averagely have mostly higher score than the average score. Furthermore, the results of environmental literacy that based on four aspects were obtained in Table 1. In each aspect of environmental literacy, the higher average for the aspects of EK, EA, ERB, and ES were in the national school of adiwiyata. While the lowest average EK was in non-adiwiyata schools, the lowest EA was in the regional adiwiyata, the lowest ERB at provincial adiwiyata, and the lowest ES at provincial adiwiyata. In general, the highest literacy value of the per aspect environment was in schools with national adiwiyata levels. For the distribution of environmental literacy scores at adiwiyata and non adiwiyata schools can be seen in Table 2. For the overall distribution of environmental literacy score based on the age of 13, 14, 15 years or more can be seen in Table 3. Environmental Literacy Distribution Based on School Predicate can be seen in Table 4.

TABLE 1: Distribution Four Aspect of Environmental Literacy.

\begin{tabular}{|c|c|c|c|c|c|c|}
\hline & N Statist & Min Statistic & Max Statistic & $\begin{array}{c}\text { Mean } \\
\text { Statistic }\end{array}$ & $\begin{array}{l}\text { Std.Dev } \\
\text { Statistic }\end{array}$ & Skewness \\
\hline Literasi & 379 & 40 & 78 & 58,96 & 7,087 & 0,147 \\
\hline EK & 379 & 18 & 88 & 54,70 & 14,514 & $-0,238$ \\
\hline EA & 379 & 51 & 84 & 68,20 & 5,815 & 0,130 \\
\hline ERB & 379 & 50 & 95 & 74,18 & 7,626 & 0,086 \\
\hline ES & 379 & 3 & 97 & 40,79 & 19,886 & 0,262 \\
\hline
\end{tabular}


TABLE 2: Distribution of Environmental Literacy for Each Indicator.

\begin{tabular}{|l|l|l|l|l|l|l|}
\hline $\begin{array}{l}\text { Predikat } \\
\text { sekolah }\end{array}$ & Stat & EK & EA & ERB & ES & Literacy \\
\hline National & Mean & 70,36 & 72,52 & 75,06 & 45,49 & 65,68 \\
\hline Provincial & Mean & 60,94 & 69,64 & 72,31 & 39,43 & 59,53 \\
\hline District & Mean & 52,94 & 66.30 & 73,64 & 42,48 & 59,42 \\
\hline $\begin{array}{l}\text { Non } \\
\text { Adiwiyata }\end{array}$ & Mean & 52,52 & 67,78 & 74,55 & 39,97 & 57,99 \\
\hline
\end{tabular}

TABLE 3: Distribution Environmental Literacy Based on Age.

\begin{tabular}{|l|l|l|l|l|l|l|}
\hline Age & Stat & EK & EA & ERB & ES & Literasi Total \\
\hline 13 & Mean & 54,45 & 68,94 & 75,98 & 41,77 & 59,83 \\
\hline 14 & Mean & 54,55 & 67,74 & 73,73 & 40,96 & 58,52 \\
\hline $15 /$ more & Mean & 55,42 & 68,39 & 72,85 & 38,97 & 58,90 \\
\hline
\end{tabular}

TABLE 4: Distribution of Environmental Literacy Based on School Level.

\begin{tabular}{|c|c|c|c|c|c|c|}
\hline \multicolumn{2}{|c|}{ Demographic } & \multicolumn{5}{|c|}{ School Level } \\
\hline & & National & Provincial & District & Non.Adi & TOTAL \\
\hline & & Mean & Mean & Mean & Mean & Mean \\
\hline \multirow[t]{3}{*}{ Age } & 13 & 66,60 & 61,83 & 61,18 & 57,82 & 59,83 \\
\hline & 14 & 65,13 & 60,58 & 58,55 & 57,60 & 58,52 \\
\hline & $15 \geq$ & 64,96 & 56,14 & 58,51 & 59,93 & 58,90 \\
\hline \multicolumn{2}{|c|}{ Total } & 66,68 & 59,71 & 59,32 & 57,76 & 58,80 \\
\hline
\end{tabular}

On the per aspect scores, the highest average of EK were at the age of 15 years or older but it did not show a significant difference of averages. In the EA aspects, the age of 13 and 15 years were not much different. The ERB score was the highest at the age of 13 years while the average ES score from all three levels of age was almost the same but the highest was 13 years old. The overall scores distribution of environmental literacy by Gender The average environmental literacy for females was higher than males. For the distribution of environmental literacy scores based on sex and school predicates can be seen in Table 5

In The score per indicator the average of EC, ERB and ES were higher in females, while the EA aspect was higher in males. For the distribution of environmental literacy scores of each aspect by gender can be seen in Table 6 .

Based on the analysis results, the researcher first conducted prerequisite analysis test that were the normality and homogeneity test. Based on result of normality test of environmental literacy data obtained the result for age 13 years had sig. score of 0.200 
TABLE 5: Environmental Literacy Based On Gender.

\begin{tabular}{|c|c|c|c|c|c|c|}
\hline \multicolumn{2}{|c|}{ Demographic } & \multicolumn{5}{|c|}{ School Level of Adiwiyata } \\
\hline & & National & Provincial & District & Non Adi & TOTAL \\
\hline & & Mean & Mean & Mean & Mean & Mean \\
\hline \multirow[t]{2}{*}{ Gender } & $\mathrm{F}$ & 66,62 & 59,17 & 60,16 & 59,26 & 59,86 \\
\hline & M & 64,74 & 60,25 & 58,48 & 56,26 & 57,73 \\
\hline \multicolumn{2}{|c|}{ Total } & 66,68 & 59,71 & 59,32 & 57,76 & 58,80 \\
\hline
\end{tabular}

TABLE 6: Distribution of Environmental Literacy Aspect Based on Gender.

\begin{tabular}{|l|l|l|l|l|l|l|}
\hline Gender & Stat & EK & EA & ERB & ES & Literacy Total \\
\hline Female & Mean & 57,00 & 67,91 & 74,49 & 42,84 & 59,86 \\
\hline Male & Mean & 51,54 & 68,60 & 73,75 & 37,97 & 57,73 \\
\hline
\end{tabular}

then the data was normally distributed. For the age of 14 years had sig. score of 0,200 then the data was normally distributed and the age of 15 years or more had sig. score of 0.081 then the data was normally distributed. Here was the result of normality test. The result of normality data test of environment literacy based on predicate of school obtained result that at adiwiyata national level had sig. score of 0.107 then the data was normally distributed, provincial adiwiyata level had sig. score of 0.200 then the data was normally distributed, adiwiyata district level had sig. score of 0,200 then the data was normally distributed, and non adiwiyata had sig. score 0.200 then the data was normally distributed.

The result of normality test of environment literacy data by sex obtained result that on females had sig. score of 0.200 then the data was normally distributed and on the males the sig. score was 0.076 then the data was normally distributed. The homogeneity test was intended to show that the sample data comes from a population that having the same variant. Environmental Homogeneity Literacy Test Result on school group and age of Sig. score 0.051; environmental literacy in school and sex groups, 203; and homogeneity of environmental literacy in age group and gender of Sig score. 0.057.

The result of hypothesis test showed the significance score of $0.000<0,05$ so that Ho was rejected, so that there was a significant difference in the students' environment literacy value between the school with the national, provincial, regional, and non adiwiyata levels. Based on result of hypothesis test showed that there was significant difference between adiwiyata rats in junior high, the higher level of adiwiyata hence the higher the value of environmental literacy. This was in line with Fera's (2014) study of environmental literacy can be enhanced by adiwiyata especially in the aspects of 
environmental knowledge. Schools that contain environmental education that is adiwiyata would provide an environment-related experience that can have a positive impact on knowledge, attitudes, and the tendency to act or behave responsibly towards the environment thereby impacting on the improvement of environmental literacy (Bogner, 1999; Culen \& Mony, 2003, Dimopoulos et al., 2008; Hart \& Nolan, 1999; Hsu, 2004; Moody et al., 2005; Ozsoy, 2012; Rovira, 2000; Roberts, 2008; Ruiz-Mallen et al., 2009; Walsh-Daneshmandi \& MacLachlan, 2006; Wang, 2009).

Environmental-based schools have a significant influence on environmental literacy supported by Krnel and Naglic research (2009), stating that the knowledge aspect of environmental literacy at school-based environments is significantly more significant than in ordinary schools. In addition, environment-based schools make students more aware of environmental issues because they are encouraged by situational factors that directly encourage students to be involved with the facilities available in schools such as recycling containers, garbage banks, green houses etc. (Spinola, 2015). According to Foster and Liney (2007) that the environment has a positive influence and instill an appreciation in many people. Schools close to the natural environment are more concerned about conservation and care than schools that do not yet have a bachelor's degree.

The result of hypothesis test shows that the significance value was $0,308>0,05$ so that Ho was accepted, so that there was no difference of literacy ability of junior high school students environment between 13,14 , and 15 years or more. This was in accordance with the research of Kroufek \& Svobodova (2016), stating age has no effect on environmental literacy on aspects of attitude across the class. The result of hypothesis test shows that the significance score of $0,004<0,05$ so that Ho was rejected, so that there was difference of literacy ability of junior high school students environment between males and females. Females have better environmental literacy skills than males. Female students have a better attitude toward their environment than male students. Gender differences in a wider perspective affect the students' environmental stance that female students are more sensitive to environmental issues (Kose et al., 2011; Cetin \& Nisanci, 2010; Mrema, 2008; O’Brien, 2007; Lin, 2004; Wong, 2004).

The result of hypothesis test showed that the significance score was $0,234>0,05$ so Ho was accepted, so that there was no interaction of literacy ability of junior high school students based on predicate level of adiwiyata school of national, province and regional by the age 13,14 , and 15 years old. The results of the environmental literacy assessment of junior high school students can be influenced by the adiwiyata school level, but the environmental literacy was not affected by age. 
The result of hypothesis test showed the signification of significance score of 0,399> 0,05 so Ho was accepted, so that there was no interaction of literacy skill of junior high school students based on predicate level of adiwiyata school of national, provincial, and regional with gender of males and females. The results of the environmental literacy assessment of junior high school students can be influenced by the level of school adiwiyata and gender. The higher the level of adiwiyata the better the environmental literacy ability. The ability of environmental literacy is also influenced by sex. Female was more proactive to the environment than males. Interaction tests showed that no interaction between sex and the degree of adiwiyata.

The result of hypothesis test showed that based on cumulative distribution frequency of Level> 3 was not more than $51 \%$ so Ho was accepted, so Most respondent (> 51\%) would not reach score at level 3 or above on environmental literacy. The results of the environmental literacy assessment of most junior high school students were at level 2 and included in the low category. The result of the assessment of the level of adiwiyata 43.3\% was at level 1 and $39.8 \%$ were in level 2 while the rest were below the level 1 and level 3. Although higher schooling schools have higher environmental literacy scores, but did not reach the level of environmental grade literacy at level 3. As for some researchers' opinions (Puk \& Behn, 2003) that environmental education in Ontario is not effective enough to influence environmental literacy among students.

\section{Conclusion}

The environmental literacy is influenced by the degree of adiwiyata and sex. But not influenced by the age. There is no interaction of environmental literacy between school and age levels, as well as school and sex levels. Most of students in Ponorogo have low environmental literacy scores.

\section{Acknowledgement}

We would like to thank school of the adiwiyata and non adiwiyata groups who provide research sites and teachers at schools that assist with the research. We would like to thank Mrs. Suciati, Miss. Murni Ramli, and validator of research instruments. 


\section{References}

[1] Chu, H., Lee, E. A., Ko, H. E., Dong, H. S., Lee, M. N., Min, B. M., \& Kang, K, H.(2007). Korean year 3 children's environmental literacy: A prerequisite for aKorean environmental education curriculum. International Journal of ScienceEducation, 29(6), 731-746.

[2] Chu,H.E.,Lee, E.A., Ko, H.R., Shin,D.H.,Lee, M.N., Min, B.M.,Kang, K.H. (2007). Korean Year 3 Children's Environmental Literacy: A Prerequisite for a Korean Environmental Education Curriculum. International Journal of Science Education Vol.29, No.6, pp. 731-746

[3] Disinger, J. F. (2005). Environmental education's definition problem. In H.R. Hungerford, W.J. Bluhm, T. L. Volk \& J. M. Ramsey (Eds.), Essential readings inenvironmental education, (3ed. pp. 17-28). Champaign, IL: Stipe.

[4] Erdogan,M., Kostova, Z., Marcinkowski, T. (2009). Components of Environmental Literacy in Elementary Science Education Curriculum in Bulgaria and Turkey. Eurasia Journal of Mathematics, Science \& Technology Education Vol. 5 (1), 15-26.

[5] Hollweg, K.S., Taylor, J. R., Bybee, R. W., Marcinkowski, T. J., McBeth, W. C., \& Zoido, P. (2011). Assessing environmental literacy: A proposed framework for the Programme for International Student Assessment (PISA) 2015. Retrieved for North American Association for Environmental Education website:http://www.naaee.net/ sites/default/files/framework/frameworkPISA2015.pdf

[6] Hsu, S. \& Roth, R. E. (1999). Predicting Taiwanese secondary teachers' responsible environmental behavior through environmental literacy variables. Journal of Environmental Education, 30(4), 11-19.

[7] Hsu, S. (2004). The effects of an environmental education program on responsibleenvironmental behaviour and associated environmental literacy variables inTaiwanese college students. Journal of Environmental Education, 35(2), 37-48

[8] Hungerford, H. (2002a). Environmental Educators. Journal of Environmental Education, 33(3), 5. Retrieved from Academic Search Complete database. Hungerford, $\mathrm{H}$. (2002b). Environmental educators. Journal of Environmental Education, 33(4), 4-9.

[9] Hungerford, H. R., Volk, T. L., McBeth, W. C. \& Bluhm, W. J. (2009). Middle School Environmental Literacy Survey. Carbondale, IL: Center for Instruction, StaffDevelopment, and Evaluation

[10] Hungerford, H.R. \& Volk, T.L. (1990). Changing Learner Behaviour trough Environmental Education. Journal of Environmental Education, 21(3), 8-21. 
[11] Karatekin, K. (2012). Environmental Literacy in Turkey Primary School Social Studies Textbooks. Procedia Social and Behavioral Sciences Vol.46, pp.3519-3523

[12] Krnel, D. \& Naglic, S. (2009). Environmental literacy comparison between eco-schools and ordinary schools in Slovenia. Science Education International, 20(1), 5-24.

[13] Muijs, D. (2011). Doing quantitative research in education with SPSS (2nd ed). London: Sage Publications.

[14] Negev, M., Sagy, G., Garb, Y., Salzberg, A., Tal, A. (2008). Evaluating the Environmental Literacy of Israeli Elementary and High School Students. The Journal of Environmental Education Vol.39, No.2, pp.3-20

[15] Negev, M., Sagy, G., Garb,Y., Salzberg, A., \& Tal, A. (2008). Evaluating theenvironmental literacy of Isreali elementary and high school students. Journal ofEnvironmental Education, 39(2), 3-20.

[16] North American Association for Environmental Education (NAAEE), (2011). National Environmental Literacy Assessment, Phase Two: Measuring the Effectiveness of North American Environmental:110

[17] Ozsoy, Sibel., Ertepinar, Hamide., dan Saglam, Necdet. (2012). Can Eco-Schools Improve Elementary School Students' Environmental Literacy Levels? Jurnal: AsiaPacific Forum on Science Learning and Teaching, Vol. 13 Issue 2/December 2012.

[18] Rahmawati, I. dan M. Suwanda. (2015). Upaya pembentukan perilaku peduli lingkungan siswa melalui sekolah adiwiyata di SMP negeri 8 Surabaya. Jurnal kajian Moral dan Kewarganegaraan, 1, 71-78

[19] Spinola, H, (2015). Environmental Literacy Comparison Between Students Taught in Eco-Schools and Ordinary Schools in the Madeira Island Region of Portugal. Science

[20] Sudarwati, T.M. (2012). Implementasi kebijakan pendidikan lingkungan hidup sekolah menengah atas negeri 11 semarang menuju sekolah adiwiyata. Tesis. Universitas Diponegoro

[21] Sukarno, Fera Maulidya, 2014. Implementasi Model Pembelajaran Investigating, Evaluating Environmental Issue And Action (IEEIA) Untuk Membangun Literasi Lingkungan Siswa SMP Universitas Pendidikan Indonesia repository.upi.edu perpustakaan.upi.edu

[22] Tim Adiwiyata Nasional, (2013). Panduan Adiwiyata.Kementerian Lingkungan Hidup Republik Indonesia

[23] Volk, T.L. \& Cheak, M.J. (2003). The Effect of an Environmental Education Program on Students, Parents and Community. The Journal of Environmental Education Vol.34, No.4, pp.12-25. 
[24] Volk, T.L. \& McBeth, W. (2005). Environmental literacy in the United States. In H. R. Hungerford, W. J. Bluhm, T. L. Volk \& J. M. Ramsey (Eds.), Essential readings in environmental education, (3ed., pp. 73-86). Champaign, IL: Stipe Publishing. 